УДК 008:640.41

\title{
СЕРВІСНА ДІЯЛЬНІСТЬ ГОТЕЛІВ В УМОВАХ СТАГНАЦІЇ ГАЛУЗІ
}

\section{SERVICE ACTIVITY OF HOTELS IN THE CONDITIONS OF STAGNATION OF THE INDUSTRY}

\author{
Онищук Наталя Вікторівна \\ кандидат економічних наук, доцент, \\ Вінницький торговельно-економічний інститут \\ Київського національного торговельно-економічного університету \\ ORCID: https://orcid.org/0000-0002-1635-0801
}

Onyshchuk Natalia

Vinnytsia Institute of Trade and Economics

of Kyiv National University of Trade and Economics

\begin{abstract}
У статті розглянуто сфери застосування сервісної діяльності готелів, що визначає тип і спрямованість стратегій готельних підприємств в умовах стагнації галузі. У свою чергу, сервісна діяльність готелів дозволяє конструювати відповідні економічні та управлінські механізми, оскільки вони визначаються саме типом впроваджуваного сервісу та обраної стратегії. При цьому будь-який готель в процесі реалізації системного підходу до визначення своєї стратегії розвитку, розглядає свою сервісну діяльність з урахуванням принципів і аспектів класифікації, отримує можливість точніше позиціонуватися на ринку, визначити фоорми просування і реалізації своїх послуг і пропозицій на ринок, які для різних типів сервісу різні. Сервісна діяльність готелів охоплює якість та безпечність послуг, впровадження нових послуг, впровадження інноваційних технологій, удосконалення маркетингової діяльності закладів розміщення.
\end{abstract}

Ключові слова: готельний бізнес, сервісна діяльність, конкурентоспроможність, сервісний процес, інновації.

В статье рассмотрены сореры применения сервисной деятельности гостини, которые определяют тип и направленность стратегий гостиничных предприятий в условиях стагнации отрасли. В свою очередь, сервисная деятельность гостиниц позволяет конструировать соответствующие экономические и управленческие механизмы, поскольку они определяются именно типом внедряемого сервиса и выбранной стратегией. При этом любой отель в процессе реализации системного подхода к определению своей стратегии развития, рассматривает свою сервисную деятельность с учетом принципов и аспектов классисикации, получает возможность точнее позиционироваться на рынке, определить формы продвижения и реализации своих услуг и предложений на рынок, которые для разных типов сервиса разные. Сервисная деятельность гостиниц охватывает качество и безопасность услуг, внедрение инновационных технологий, маркетинговую деятельность средств размещения.

Ключевые слова: гостиничный бизнес, сервисная деятельность, конкурентоспособность, сервисный процесс, инновации.

The consequences of the global crisis in the hotel pandemic, in particular, the search for solutions to gradually stagnate the industry, identify problems and prospects for the hotel business in the country remain unresolved, debatable, need clarification and further development, which necessitates this research. The purpose of the article is to define and describe service activities in the hotel business as a tool to increase its competitiveness. The following methods were used in the research process: theoretical generalization, abstract-logical and retrospective analysis - to study the basic principles of the hotel business. According to the results of the study it is determined that in modern conditions one of the phenomena that effectively affects the production process in the hotel business was the progress of service activities, which includes the use of a wide range of modern information technologies, customer security technologies, online and mobile technologies. The introduction of mobile devices in the form of "contactless support" in the hotel business, the introduction of artificial intelligence, benchmarking, software in the management of the hotel complex and management, the use of environmental innovations. In order to respond to the economic crisis and maximize the functioning of the market of hotel services in Ukraine in the current situation, the following areas are proposed: direct participation and support of the state in the implementation of large investment projects; increasing the list of additional services; improving the quality and culture of customer service; bringing highways in proper condition that meets international 
standards, finding the latest strategies and approaches to hotel business management, intensive implementation and use of innovative information technologies, further formation and development of national hotel chains, mainly in the segment of 2-3 stars, without direct competition with international hotel chains; on the other - in the development of small business in the sector of creating mini-hotels designed for low-cost tourism.

Keywords: hotel business, service activity, competitiveness, service process, innovations.

Постановка проблеми. Поточний рік став найважчим для індустрії гостинності: локдаун, пандемія, віддалена робота, обмеження на переміщення, падіння доходів населення все це призвело до масштабних змін в операційних процесах бізнесу, в поведінці і уподобаннях гостей готелів.

Багато засобів розміщення закрилися, багато мають погану фрінансову стійкість і можуть не витримати боргового навантаження. Все, що відбувається сприймається учасниками ринку дуже тривожно. Одночасно з цим йде процес відтоку професійних кадрів 3 профресії - люди розуміють, що їх навички зараз нікому не потрібні і не можуть бути гідно оплачені. Як наслідок, не приділяється належної уваги сервісу обслуговування.

Галузь гостинності зараз як ніколи потребує перегляду цінностей, в радикальному оновленні відповідно з поточною ситуацією.

Аналіз останніх досліджень і публікацій. Значний внесок у адаптацію готельних підприємств під час пандемії зробили фрахівці з Асоціації індустрії гостинності України [1], Всеукраїнської громадської організації «Асоціація малих готелів та апартаментів України» [2], Асоціації готелів і ресторанів України [3]. Питанням розвитку готельного бізнесу присвячені праці С.С. Галасюк, О.В. Шикіної [4], О.Ю. Давидової [5], Л.Д. Завідної [6], О.І. Мілашовської, А.В. Гриняло, М.М. Удут [7].

Виділення невирішених раніше частин загальної проблеми. Незважаючи на значну кількість наукових праць і значні досягнення в цій галузі, питання наслідків спричинених світовою кризою в умовах пандемії на готельний бізнес, зокрема, пошук рішень для поступового виходу з стагнації, покращення сервісної діяльності готелів залишаються невирішеними, дискусійними, потребують уточнення і подальшого розвитку, що й обумовлює необхідність даного наукового дослідження.

Формулювання цілей статті (постановка завдання). Виокремити критерії та описати клієнт орієнтований сервіс в готельному бізнесі як інструмент підвищення його конкурентоспроможності.

Виклад основного матеріалу дослідження. Тактичні заходи, що вживаються власниками бізнесу і (або) управлінцями, дають можливість вижити і встояти. По-перше - чітке і скрупульозне фрінансове планування шляхом жорсткого бюджетоутворення, по-друге це прогнозування та оперативне задоволення потреб гостей, перегляд (в разі необхідності) концепції підприємства, цільової аудиторії, створення корпоративної культури управління сервісом і підбір та перенавчання персоналу (за рахунок внутрішніх ресурсів).

Сервіс в даний час одна з головних конкурентних переваг готелів. Насправді існує зовнішній і внутрішній сервіс. Зовнішній - це те, що ми бачимо, як споживачі і не важливо, що від нас приховано. Звідси виникають фрормалізовані стандарти роботи, які ґрунтуються не на бажанні працівника догодити гостю, а на фрормальних зобов'язаннях працівника перед роботодавцем (стандартах, посадових інструкціях, положеннях). У таких випадках споживач стикається 3 «американською посмішкою», яка не має нічого спільного з щирістю.

Внутрішній сервіс готелю - внутрішня система відносин, яка, як правило, фрормується, проектується і відбивається на відношенні до споживача і якості надаваних йому послуг.

Клієнт-орієнтованість вкрай важлива в ссрері гостинності. Тому що це можливість фоормувати додатковий потік споживачів, забезпечуючи глибоке розуміння, а також задоволення основних потреб споживачів. Клієнт-орієнтованість - це перехід співробітника від стану «повинен» (формальний сервіс) в «сервісний» стан. Техніки клієнт-орієнтованості лежать в основі [1]:

1. Знання цільової аудиторії і принципів ії поведінки. Персоналу важливо розуміти, що змушує гостя повертатися в засіб розміщення.

2. Уміння налаштовуватися на цільову аудиторію і приймати іï.

3. Уміння визначити потреби гостя.

4. Знання технік фрормування гостинної лояльності.

5. Формування сервісної команди. Всі рівні персоналу спочатку повинні бути клієнт-орієнтованими і гостинними.

6. Уміння підтримувати фокусування співробітників на клієнт-орієнтованості шляхом мотивації.

7. Побудова комунікації зі споживачем. Техніки Small Talk.

8. Управління конфрліктами. 
Співробітники на всіх рівнях повинні усвідомлювати важливість надання гостям високоякісних послуг. Це те, що робить сервіс яскравим і незабутнім, а також допомагає завойовувати лояльність гостей.

Незважаючи ні на що, ні один готель не може задовольнити всіх своїх гостей. Чим швидше готель знайде свою цільову аудиторію, тим точніше можна зробити настройку сервісу [7, с. 86].

Для визначення цільової аудиторії складають портрет цільової аудиторії, який дає точну характеристику споживачам. Завдання формування портрета цільової аудиторії:

- складання офрерти (пропозиції). При складанні портрета клієнта, ми виділяємо його проблему;

- опрацювання вигод. Знаючи свого клі-

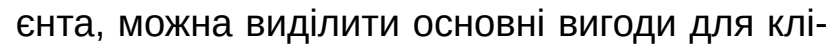
єнта, які виділяють готельний продукт серед конкурентів;

- визначення ключових тригерів. Вивчивши поведінку цільової аудиторії, можна вибрати тригери, які впливають на мотивацію при виборі готелю.

Бізнес з низькими показниками залучення та утримання клієнтів малоефективний.

Існує 5 критеріїв за якими можна оцінити його клієнт-орієнтованість [4, с. 54]:

1. Коефріцієнт утримання клієнтів (Customer Retention Rate) - показує наскільки есрективно працює служба підтримки клієнтів, і пророкує темпи зростання бізнесу. Retention rate показує, скільки клієнтів залишилися з готелем за певний період часу. Наприклад, можна виміряти коефріцієнт утримання за рік, місяць або тиждень.

Хоча загальноприйнятої фрормули для розрахунку коефріцієнта утримання немає, Джеффр Хеден 3 Inc пропонує точний спосіб вимірювання утримання клієнта. Вважається, чим вище CRT - тим краще.

(Retention Rate $=((\mathrm{CE}-\mathrm{CN}) / \mathrm{CS})) \times 100)$,

де CE = Кількість клієнтів на кінець періоду.

$\mathrm{CN}=$ Кількість нових клієнтів, придбаних за період.

CS = Кількість клієнтів на початок періоду.

2. Довічна цінність клієнта (Customer Lifetime Value)

Показник customer lifetime value (LTV) - це проекція потенційного доходу, який можна отримати від клієнта. Цей критерій розраховується на підставі попередньої купівельної поведінки споживача. Відштовхуючись від LTV, можливо визначити, скільки доцільно витрачати на залучення клієнтів, і розрахувати ефективність інвестицій (ROI).

(Customer Lifetime Value $=$

$=($ Середній чек) $x$ (Кількість повторних

продажів) x (Середній час утримання))

щоб зрозуміти, чи працюють стратегії утримання, потрібно відстежувати показник LTV: з часом він повинен рости. Це означає, що люди витрачають більше і замовляють частіше, тому що їхні стосунки з готелем розвиваються.

3. Коефріцієнт повторних звернень (Repeat Purchase Rate) Repeat purchasing rate - це відсоток клієнтів, які замовили продукти (послуги) більше ніж один раз. Коефріцієнт повторних звернень показує, скільки клієнтів повертаються після першого замовлення - a, значить, їм можна користуватися як індикатором retention. Щоб розрахувати показник, потрібно розділити кількість «повторних» клієнтів на загальну кількість клієнтів.

(Repeat purchase rate $=$ Кількість повторних клієнтів / Загальна кількість клієнтів)

4. Коефріцієнт використання акційних пропозицій (Redemption Rate) Один з ефективних способів стимулювати повторні звернення. Але яку частку акційних пропозицій клієнти реально використовують? Розрахуємо коефіцієнт redemptiont:

(Redemption rate $=$ Кількість використаних

акційних пропозицій / Загальна кількість акційних пропозицій)

За коефріцієнтом redemption можна судити, наскільки акції готелів мотивують гостей купити послугу. Якщо redemption rate низький (близько 20\%), то потрібно аналізувати, чому продукт не купують. Можливо, умови акції недостатньо вигідні - або споживачам просто більше не цікава така пропозиція.

5. Індекс споживчої лояльності (Net Promoter Score)

NPS (Net Promoter Score) - це індекс споживчої лояльності, який допомагає готелю визначити ставлення клієнтів до продукту/послуги і готовність цей продукт рекомендувати друзям і знайомим. Рівень NPS повинен показувати, наскільки добре працює утримання покупців. NPS розраховується за фрормулою:

(NPS = Відсоток рекомендувачів (промоутерів) - Відсоток критиків (детракторів))

Щоб обчислити розмір 1 і 2 груп клієнтів, проводять спеціальні опитування. Опитування проводять в е-mail або sms-розсилках, по телефрону, або особисто клієнтам задається одне просте запитання: «Як ви оцінюєте ймовірність 
того, що ви будете рекомендувати послуги готелю іншим, за шкалою від 0 до 10?».

Найвищі оцінки (10 і 9) припадають на частку промоутерів. Чим вище їх відсоток, тим оптимістичніше відчуває себе готель в плані лояльності клієнтів.

Відсоток критиків або детракторів складають ті, хто поставив оцінку 6 і нижче. Це ті самі клієнти, які можуть залишити негативний відгук про цей готель, або його послуги. Або вже зробили це. Вибірка для опитування повинна бути репрезентативною.

При простому розрахунку показника NPS частка клієнтів, які обрали оцінки 8 і 7, не враховується: це в масі своїй пасивні клієнти (нейтрали), які підуть, якщо у конкурентів з'явиться продукт / послуга, що влаштовує їх більше, ніж ваш. Але слід пам'ятати, що в це число можуть входити критики, які просто відмовилися відповідати на питання.

Для більш точних даних слід окремо оцінити групу нейтралів - 3 якою ймовірністю вони можуть бути віднесені, або до промоутерів, або до детракторів. Або в яку групу вони потраплять, якщо готель нічого не буде робити. Рівень NPS стимулює готель до певних дій в будь-якому випадку.
Якщо він досить високий (> 60\%), готель може розраховувати на переважну частку в своїй ніші. Якщо індекс лояльності нижче $50 \%$, варто переглянути роботу над утриманням лояльних клієнтів.

Важливо оцінювати NPS щодо інших показників, наприклад, прибутку. Якщо прибуток зростає, а індекс лояльності падає, недалеко той час, коли конкуренти запропонують альтернативу вашому продукту/послузі за меншу ціну. Крім того, слід уважно стежити за коефріцієнтом утримання (Retention Rates) як за маркером «здоров'я» клієнтів. Він показує прихильність до продукту / послуги, конкурентні переваги і здатність впливати на ціну. Задоволені клієнти - кращий довгостроковий ресурс. Вони запускають сарафранне радіо, показують потенційним покупцям приклад довіри до продукту і сприяють поліпшенню цього продукту.

Таким чином, на основі запропонованого клієнт-орієнтованого сервісу було визначено цільовий сегмент споживачів для заміського комплексу (ЗК) «Баттерфляй », який знаходиться за адресою: м. Вінниця, Літинський район, 20-й кілометр Хмельницького шосе, село Садове.

Пакет «П`ятиденний»

Варіант базовий (на 2-х дорослих на 5 днів 4 ночі) (+1 дитина до 10 років безкоштовно).

Таблиця 1

Послуги пакету «П`ятиденний»

\begin{tabular}{|c|c|}
\hline Проживання у номері категорії & Стандарт \\
\hline Харчування & BB*/FB на вибір \\
\hline $\begin{array}{l}\text { Можливість перебувати на території комплексу } \\
\text { без додаткової оплати вхідного квитка }\end{array}$ & з 09:00 дати заїзду до 23:00 дати виїзду \\
\hline $\begin{array}{l}\text { Активна анімація та користування розвиненою } \\
\text { індрраструктурою комплексу*夫 }\end{array}$ & Згідно загального грасріку роботи атракцій \\
\hline Транссрер (від/до) зал. вокзалу/аеропорту & За запитом \\
\hline
\end{tabular}

Вартість від: ВВ $^{\star}=6200=5900$ грн. $\mathrm{FB}=9050=8550$ грн

Варіант Люкс (на 2-х дорослих на 5 днів 4 ночі + до 2-х дітей).

Таблиця 2

Послуги пакету «П`ятиденний Люкс»

\begin{tabular}{|l|l|}
\hline Проживання у номері категорії & Люкс Сімейний \\
\hline Харчування & All \\
\hline $\begin{array}{l}\text { Можливість перебувати на території комплексу } \\
\text { без додаткової оплати вхідного квитка }\end{array}$ & 3 09:00 дати заїзду до 23:00 дати виїзду \\
\hline $\begin{array}{l}\text { Активна анімація та користування розвиненою } \\
\text { інфраструктурою комплексу*夫 }\end{array}$ & 3гідно загального грасріку роботи атракцій \\
\hline Трансфер (від/до) зал. вокзалу/аеропорту & За запитом \\
\hline Користування аквагіркою & Безлімітний спуск \\
\hline Релакс масаж & 2 сеанси \\
\hline
\end{tabular}

Вартість від: All=13000 = 10000 грн. 
Пакет «Вікенд»

Варіант базовий: на 2-х дорослих на 3 дні 2 ночі (+1 дитина до 10 років безкоштовно).

Таблиця 3

Послуги пакету «Вікенд»

\begin{tabular}{|l|l|}
\hline Проживання у номері категорії & Стандарт \\
\hline Харчування & ВВ/FВ на вибір \\
\hline $\begin{array}{l}\text { Можливість перебувати на території комплексу } \\
\text { без додаткової оплати вхідного квитка }\end{array}$ & з 09:00 дати заїзду до 23:00 дати виїзду \\
\hline $\begin{array}{l}\text { Активна анімація та користування розвиненою } \\
\text { інфрраструктурою комплексу夫* }\end{array}$ & 3гідно загального графріку роботи атракцій \\
\hline
\end{tabular}

Вартість $\mathrm{BB}^{*}=3500=3300$ грн.

Варіант Люкс (на 2-х дорослих на 3 дні 2 ночі + до 2-х дітей - доплати згідно обраного типу харчування та віку дітей).

Таблиця 4

Послуги пакету «Вікенд Люкс»

\begin{tabular}{|l|l|}
\hline Проживання у номері категорії & Люкс Сімейний \\
\hline Харчування & BВ/FB на вибір \\
\hline $\begin{array}{l}\text { Можливість перебувати на території комплексу } \\
\text { без додаткової оплати вхідного квитка }\end{array}$ & з 09:00 дати заїзду до 23:00 дати виїзду \\
\hline $\begin{array}{l}\text { Активна анімація та користування розвиненою } \\
\text { iнфраструктурою комплексу** }\end{array}$ & Згідно загально графріку роботи атракцій \\
\hline
\end{tabular}

Вартість від: ВB $^{\star}=4300=4100$ грн. FB* $=6200=5900$ грн.

Динаміка показників експлуатаційної діяльності ЗК «Баттерфляй»

Таблиця 5

\begin{tabular}{|l|c|c|c|c|c|}
\hline \multicolumn{1}{|c|}{ Показники } & $\begin{array}{c}\text { Одиниця } \\
\text { виміру }\end{array}$ & $\mathbf{2 0 1 9}$ p. & $\mathbf{2 0 2 1}$ p. & $\begin{array}{c}\text { Biдхилення, } \\
\text { +l- }\end{array}$ & $\begin{array}{c}\text { Темп росту } \\
\text { \% }\end{array}$ \\
\hline \multicolumn{1}{|c|}{$\mathbf{1}$} & $\mathbf{2}$ & $\mathbf{3}$ & $\mathbf{4}$ & $\mathbf{5}$ & $\mathbf{6}$ \\
\hline Загальна площа на кінець року & м $^{2}$ & 3050 & 3050 & 0 & 0 \\
\hline Загальна житлова площа номерів & м $^{2}$ & 2620 & 2620 & 0 & 0 \\
\hline Одноразова місткість & місць & 300 & 300 & 0 & 0 \\
\hline Загальна кількість номерів, в т.ч.: & одиниць & 110 & 110 & 0 & 0 \\
\hline Напівлюкс & одиниць & 10 & 10 & 0 & 0 \\
\hline Люксів & одиниць & 15 & 15 & 0 & 0 \\
\hline Двомісних номерів & одиниць & 65 & 65 & 0 & 0 \\
\hline Трьохмісних номерів & одиниць & 20 & 20 & 0 & 0 \\
\hline $\begin{array}{l}\text { Можлива пропускна спроможність } \\
\text { готелю }\end{array}$ & ліжко/ діб & 109500 & 109500 & 0 & 0 \\
\hline Коесріцієнт завантаження & \% & 0,69 & 0,79 & 0,10 & 1 \\
\hline Кількість обслуговуваних туристів & осіб & 7555 & 8650 & 1095 & 1,1 \\
\hline тому числі іноземців & осіб & 560 & 400 & -160 & 0,7 \\
\hline $\begin{array}{l}\text { Середній термін перебування } \\
\text { одного вітчизняного туриста }\end{array}$ & діб & 2 & 4 & 2 & 0 \\
\hline $\begin{array}{l}\text { Середній термін перебування } \\
\text { одного іноземного туриста }\end{array}$ & діб & 2 & 2 & 0 & 0 \\
\hline Середня вартість однієї ліжко/доби & грн. & 950 & 950 & 0 & 0 \\
\hline $\begin{array}{l}\text { Фінансовий результат від звичайної } \\
\text { діяльності }\end{array}$ & млн. грн. & 71,777 & 82,179 & 10,402 & 1,1 \\
\hline Загальний рівень рентабельності & \% & 0,66 & 0,76 & 0,10 & 1 \\
\hline
\end{tabular}


Цільовим сегментом споживачів комплексу у 2020-2021 рр. стали сімейні пари з дітьми. Зростання попиту на послуги ЗК «Баттерфрляй» у цей період можна пояснити тим що, під час пандемії споживачі надавали перевагу заміському відпочинку, закриття кордонів призвело до зростання попиту на внутрішній туризм. Для більш комфортного сімейного відпочинку у заміському комплексі були розроблені пакетні тури, які продавались споживачам у 2020-2021 pp. [8].

Після впровадження клієнт-орієнтованого сервісу розглянемо показники експлуатаційної діяльності ЗК «Баттерфляяй» за період 2019-2021 pp.

Аналіз даних таблиці 5 свідчить, що 3К «Баттерфрляй» здійснює господарську діяльність успішно. Враховуючи запити гостей на відпочинок в умовах карантинних обмежень, заклад розробив пакетні тури з різним видом сервісу, що дало можливість збільшити кількість відвідувачів на 1095 осіб, порівняно 3 базовим 2019 р. Збільшити середній термін перебування одного вітчизняного туриста 3 2 до 4 днів, покращити фрінансовий результат від звичайної діяльності на 10,402 млн. грн.

Висновки. Пандемія і режим самоізоляції виявилися важким випробуванням для засобів розміщення. Будь-яка криза призводить до того, що виживають найсильніші. Єдиний рецепт збереження бізнесу - це постійна робота над поліпшенням того, що зроблено. Щоб планувати своє майбутнє, готелям потрібно постійно працювати над оптимізацією процесів, зниженням витрат, бути соціально активними і, звичайно, працювати над оновленням цільової аудиторії.

\section{СПИСОК ВИКОРИСТАНИХ ДЖЕРЕЛ:}

1. Асоціація індустрії гостинності України. Ооріційний сайт. URL: http://aigu.org.ua/ (дата звернення: 10.07.2021).

2. Всеукраїнська громадська організація «Асоціація малих готелів та апартаментів України». ВГО «АМГАУ». URL: https://vkursi.pro/card/vho-amhau-35142910 (дата звернення: 10.07.2021).

3. Ассоциация гостиниц и ресторанов Украины. URL: https://www.facebook.com/search/top/ (дата звернення: 10.07.2021).

4. Галасюк С.С., Шикіна О.В. Організаційно-економічні засади функціонування малих готелів : монограсрія. Одеса, 2015. $281 \mathrm{c}$.

5. Давидова О.Ю. Формування системи інноваційного управління розвитком підприємств готельно-ресторанного господарства. Бізнес Інформ. 2017. № 11. С. 459-464.

6. Завідна Л.Д. Готельний бізнес: стратегії розвитку : монограсрія. Київ, 2017. 600 с.

7. Мілашовська О.І., Гриняло А.В., Удут М.М. Інноваційний потенціал підприємств готельно-ресторанного бізнесу. Економіка та суспільство. 2017. Вип. 8. С. 431-435.

8. Офріційний сайт заміського комплексу «Баттерфляй» URL: https://butterfly.vn.ua (дата звернення: 20.07.2021).

\section{REFERENCES:}

1. The Association of hospitality industry of Ukraine. Official site. Available at: http://aigu.org.ua/ (accessed 10 Jule 2021).

2. All-Ukrainian public organization "Association of small hotels and apartments of Ukraine". VGO "AMGAU". Available at: https://vkursi.pro/card/vho-amhau-35142910 (accessed 10 Jule 2021).

3. The Association of hotels and restaurants of Ukraine. Available at: https://www.facebook.com/search/top/ (accessed 10 Jule 2021).

4. Galasyuk, S.S., Shikina, O.V. (2015) Organizational and economic principles of operation of small hotels: monograph. Odessa, 281 p. (in Ukrainian)

5. Davydova, O.Yu. (2017) Formation of a system of innovative management of the development of hotel and restaurant enterprises. Biznes Inform, no. 11, pp. 459-464. (in Ukrainian)

6. Zavidna, L.D. (2017) Hotel business: development strategies: monograph. Kyiv, 600 p. (in Ukrainian)

7. Milashovska, O.I., Grynialo, A.V., Udut, M.M. (2017) Innovative potential of hotel and restaurant business enterprises. Ekonomika ta suspilstvo, iss. 8, pp. 431-435. (in Ukrainian)

8. ZK «Batterfliai» Official site. Available at: https://thepage.ua/ua/exclusive/sho-stanetsya-z-gotelyamicherez-koronavirus (accessed 20 Jule 2021). 